\title{
Measuring Innovation Quality: A Patent Analysis
}

\author{
Elona Marku ${ }^{1}$ \\ ${ }^{I}$ (Department of Economics and Business/ University of Cagliari, Italy) \\ Corresponding Author: Elona Markul
}

\begin{abstract}
Patents have been widely used in innovation literature as a reliable and meaningful measure of innovation performance. However, existing research has mostly used the mere number of patents as a rough indicator of innovation success, lacking to provide insights on innovation quality. Additionally, less is known about how firms are grouped in highly competitive markets and which are the strategies adopted in their inventive activities. To better understand these dynamics, this paper aims to investigate the innovation quality of firms operating in a high-tech industry employing multiple patent-based indicators. Explorative findings on patent strategies as well as patent trends are discussed.
\end{abstract}

Keywords - innovation, patents, quality, technological impact, originality, generality

\section{Introduction}

Patents have been broadly used in innovation literature as a reliable and meaningful measure of innovation performance [1], [2], [3], [4], [5], [6], [7], [8], and [9]. By definition, patents grant to their owners an exclusive monopoly over the use of a novel, non-obvious, and industrially applicable invention. Inventions may require time to be granted, and the whole patenting process may be costly for firms and inventors. Hence, the inventions protected are expected to be valuable for firms allowing them to generate rents from their future commercialization [10], [11], and [12]. Thus, patents can unveil insights on firms' inventive and innovation activities.

Early innovation research has used R\&D outputs (i.e., the number of patents) as a rough indicator of innovation performance [13], [14], [15], and [16]. More specifically, [17] found that the value of a firm patent portfolio is concentrated in a few patents. Also, [18] recognized that the number of patents is not a good measure of innovation performance because it does not capture the patents' importance. Instead, [18] observed a close relationship between patent citation-based indicators and value of innovation. Later, [19] validated patent citations as a better indicator of technological impact and importance in comparison to the simple patent counts.

Although the existing studies have widely analyzed the patent and R\&D relationship proposing different models [20], they lack to provide insights on the quality of innovation and particularly on how firms are grouped in highly competitive markets according to the strategies adopted in their inventive activities. To better understand these dynamics, this study examines 155 firms operating in the U.S. communications industry. This context was chosen because innovation in this industry is essential for firms to compete successfully and gain a competitive advantage [21], the high-density of the patenting activity [22], [23], and the usefulness of patent analysis if applied to this industry [24]. Innovation quality measures, namely, technological impact, the invention's originality, and generality have been calculated. We also account for the size of patent portfolios. Cluster analysis and technology trends have been considered for the investigation of industry homogeneity and search strategies. Explorative findings are discussed.

This paper is organized as follows. In section 2, we summarize the literature background on patent analysis and indicators of innovation quality. Section 3 is devoted to the methodology applied, whereas in section 4, we describe the primary results obtained. Finally, discussion, conclusion, limitations, and future research are included in section 5.

\section{Literature Background}

Patent analysis is a widespread method used to transform patent information into in-depth insights on firm innovation performance [25]. The innovation literature has pointed out the significant correlation between $\mathrm{R} \& \mathrm{D}$ input and inventive performance, highlighting the relationship between the R\&D expenditure and the number of patents produced [21] and [26]. In particular, [27] showed that product innovations are likely to be protected by patents while process innovations often are protected by secrecy. The other interesting relationship is the one related to patents and financial performance: if a firm grants patents frequently, it means that it has sufficient capabilities to generate inventions, affecting the economic returns positively. Because firms decide to 
patent for multiple reasons, patent analysis represents a useful tool for investigating firm strategies. For instance, most firms grant patents to find intellectual protection, to increase their reputation, to improve their position in negotiations; other firms choose to grant patents for creating barriers along essential inventions and consequently block their competitors.

Furthermore, patent analysis is used for monitoring innovation trends, identifying technological change and convergence at a firm- and industry-level [20], [29], and [30]. Indeed, [12] gauged technological change using not only innovation surveys but also patents. Additionally, patent trends can be used to analyze technology patterns and trajectories, [31] showed that the rapid increase of the patenting activity in the ' $90 \mathrm{~s}$ reflected the substantial increase of the R\&D expenditure. Besides, [32] showed that the analysis of the technology trends is more reliable when examining big portfolios, the bias rises significantly for firms with a few patents. Patent analysis can be used in the evaluation of mergers and acquisitions, and alliances, referring to the different aspects concerning the transaction, for example, the targeting, the due-diligence, the target's or acquirer's inventive performance [7], [8], and [9].

More specifically, innovation scholars have shown a great interest in analyzing patent citation data [7], [8], [9], [33], and [34]. Patent citation analysis is a bibliometric technique that links patents in the same way that the science citations link the papers' references [33], [35], [36], and [37]. Patent citations have been primarily used in three lines of research: as a measure of patent quality [1], [2], [3], [4], [5], [6], [7], [8], [18], [38], as a measure of knowledge flows and spillovers [39], [40], [41], and as a tool for the examination of technology structure [33], [42]. The term "quality" has been often used to emphasize both the technological and value dimensions of innovation [43]. [18] was the first to introduce patent forward citations as a measure of innovation quality suggesting that patents with a high number of forward citations are the most valuable. [40] used citations as proxies for both technological impact and knowledge spillovers. [44] used patent citations to measure the R\&D impact. [45] showed that the size of the invention is positively linked with citation counts. [47] used citation-based patent stock as patent indicator and assumed that the economic value of a single patent is proportional to its forward citations, similarly to R\&D. [48] showed that citation stocks have a significant impact on Tobin's q. Firms that own highly cited patents show the ability not only to innovate but also to influence further technological developments [24]. The number of forward citations can be used as a proxy for patent quality [45] and [46]. [49] observed that patent citation information is useful for investors to judge the future profit-earning potential of firm innovation activities. [50] found that firm market value increases at the time patents receive citations as they are perceived a signal of portfolio importance. Moreover, a patent may cite non-patent literature; this often happens in the pharmaceuticals where patents are highly connected with scientific research [25].

Following [18] and [38], in this paper we conceive the quality of innovation in terms of technological impact of an invention, originality, and generality. The measure of impact regards the technological importance of patent [43]. A high number of citing patents suggests that many subsequent inventions have been built upon that specific technology. However, [48] showed that a patent granted recently cannot be fully appreciated using patent citation analysis because it needs time before the accumulation of information on its forward citations. The originality index was first introduced by [51] and then resumed by [38]. This measure indicates the breadth of technological knowledge synthesized in an invention [7], [8], and [9]. If an invention is built upon different technology domains, it is considered to be more "original." Higher the number of these technology fields, higher the invention's degree of originality is expected to be. The generality index measures the breadth of applicability of an invention across different technology domains. When patent citations belong to many different technology fields, it means that the technology embodied in the focal patent can be considered "general" across domains [51].

\section{Methodology}

In the last decades, the communications industry has been the protagonist of several revolutions such as the diffusion of voice, data, and video transmission. In the U.S.A, one of the most critical events in this industry occurred in 1984 when the monopolist AT\&T was subdivided into several companies allowing the rise of firms like Time Warner, Hughes Electronics, and Qualcomm Wireless. According to [21], the communications industry is one of the industries in which innovation is fundamental to the firms' survival, and firms have myriad of patents. Also, [22] and [23] showed that semiconductor firms have a high-density patenting activity. [38] observed that the communications industry has the highest inventions' generality of applicability in a broad range of technology fields, further making this industry interesting for a more in-depth analysis. [24] suggest that the patent analysis is not useful in all sectors, but it is more applicable to the telecommunications, information technology, pharmaceuticals, biotechnology, chemicals, and automotive [33]. Hence, a patent analysis is particularly suitable for this industry.

In this study, we selected 155 firms operating in the U.S. communications industry between 1995 and 2009. We chose this time frame to capture the internet bubble as well as the digital transformation experienced 
during these years. Patent information was retrieved using the Derwent Innovation Index database; the sample included more than 120.000 patents and their citations, both backward and forward. Finally, we applied cluster analysis to gather firms according to their degree of similarity along four variables: technological impact, originality, generality, and the size of the patent portfolio.

\section{Variables}

Following the methodology proposed by [38], backward and forward citations were used to measure the indicators of innovation quality, namely, technological impact, originality, and generality. The gauge of technological impact captures the influence of a patented invention on subsequent inventions; higher is this influence, higher will be the number of citations an invention receives. The measure of technological impact is calculated as the total number of forward citations. As citations are influenced by time, the value of this indicator has been normalized using the industry average for each specific year. Moreover, we considered the size of the patent portfolio calculated as the simple count of the number of patents.

In particular, the originality index considers the classification codes of the backward citations and it is calculated as follows:

$$
\text { Originality }_{i}=1-\sum_{j=1}^{n_{i}} s_{i j}^{2}
$$

$s_{i j}$ represents the forward citations of patent $i$ (expressed in percentage terms) that belong to the classification code $j$, out of $n_{i}$ patent technology classes. Patents whose backward citations are classified under the same code will have an originality index equal to zero. The value will rise as the number of technology classes goes broader.

The generality index captures the degree of applicability of a technology on further inventions. Different from the originality index, the generality index uses the information extracted from forward citations. It is defined following [38] and [51]:

$$
\text { Generality }_{i}=1-\sum_{j=1}^{n_{i}} t_{i j}^{2}
$$

$t_{i j}$ represents the forward citations of patent $i$ (expressed in percentage terms) that have classification code $j$, out of $n_{i}$ classification codes. Patents having their forward citations spread on many technology domains will have a high value of this indicator.

\section{Results}

Graph 1 shows the number of patents granted in the 15-year timespan. Two picks are observed, the first in 1999 and the other in 2005, additionally, there are two decreases of the industry's patenting activity, the first with the burst of the internet bubble and the second after 2005. The pick of 2005 with 9.255 patents granted is strongly influenced by the intensive inventive activity of firms such as Sony Corp., General Electric Co., and AT\&T.

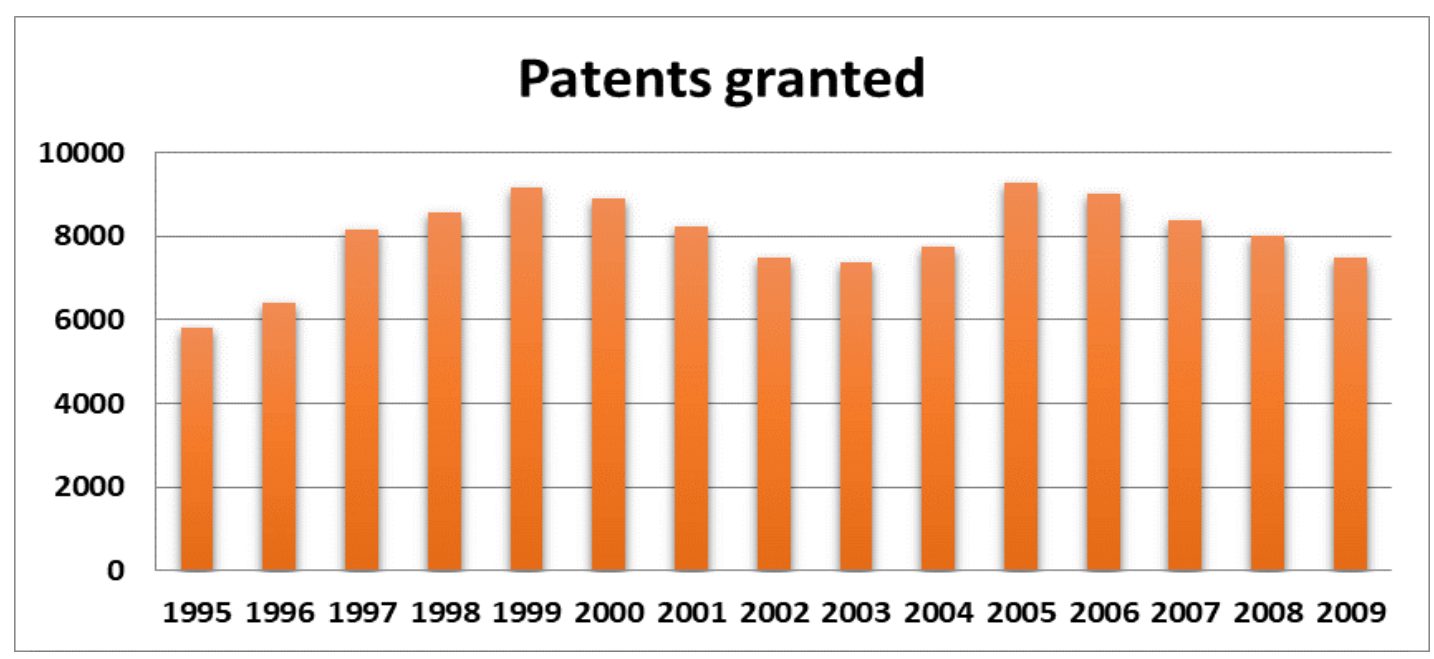

Graph. 1: The Patents of the 155 companies examined.

Graph 2 depicts patent trends for firms with more than 1.000 patents. Now it is clear the significant influence of the patent portfolio of Sony Corp. Also, AT\&T follows a similar pattern like Sony Corp., although with fewer patents; both have picks in 1997 and 2005 and then a constant decrease. Interestingly, the patenting 
activity of Lucent Technologies dropped from 1998 to 2009. It should be added that Lucent Technologies in 2006 was merged with Alcatel, for this reason, the number of patents might have fallen drastically. In contrast, Research in Motion, a very little company formed in 1984, at the beginning it had a few patents while in 2009 its portfolio included 608 patents.

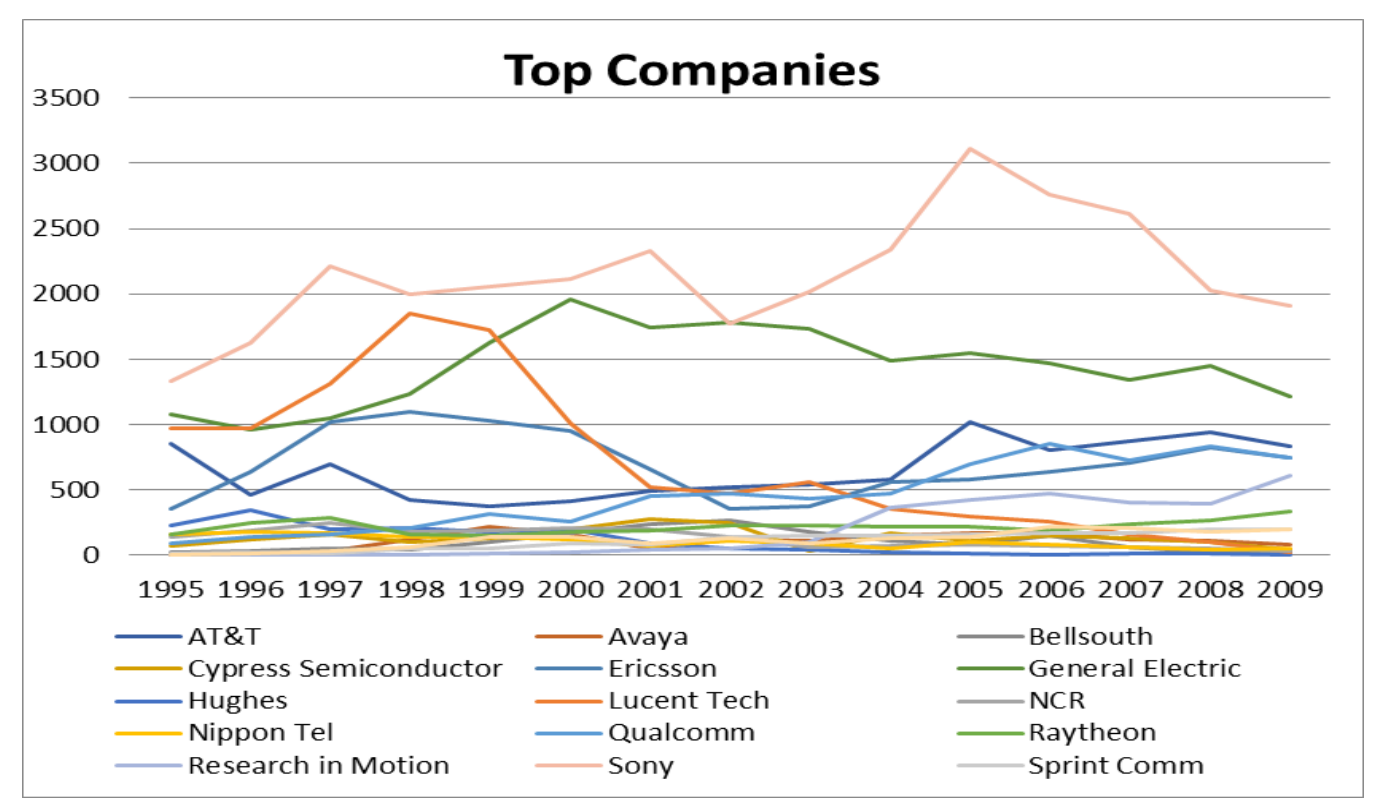

Graph. 2: Trend of the patent counts for top companies.

Table 1 summarizes the results of the cluster analysis with four variables (technological impact, originality, generality, and size of the patent portfolio), four groups emerge. Table 2 includes a high-low innovation quality for each cluster.

\begin{tabular}{|c|c|c|c|}
\hline Cluster 1 & Cluster 2 & Cluster 3 & Cluster 4 \\
\hline AT\&T & AAT & $8 \times 8$ & ACT Tel \\
\hline Ericsson & Allied & Arch Wireless & Advanced Telecom \\
\hline General Electric & Americ Mob Sat & ATG & Alere \\
\hline Lucent Tech & Americ Telecare & Atlantic Signal & Ameritech \\
\hline Qualcomm & Armstrong World & Avaya & Broadband Wireless \\
\hline \multirow[t]{26}{*}{ Sony Corp. } & Cablevision & Bellsouth & Calamp \\
\hline & Centennial Tech & Black Box & Century Comm \\
\hline & Certegy & CenturyLink & Clearwire \\
\hline & Charter Comm & Cogent Tech & Corridor Systems \\
\hline & Coherent Logix & Comm and Power & Crown Castle \\
\hline & Comcast & Cox Comm & EMS Tech \\
\hline & Consolidated Edison & Deutsche Telekom & Flash Comm \\
\hline & Cypress Semiconductor & DirecTV & Global Tel \\
\hline & EchoStar & FTS & Globalstar \\
\hline & Enron & Hughes & Integra Tech \\
\hline & Equinix & Infowave Software & Intercontinental Exchange \\
\hline & First World Comm & Insight & Intrado \\
\hline & Gemstar TV Guide & Intek Global & Iridium \\
\hline & General Dynamics & Inter Tel & LCC \\
\hline & ICG & ITXC & Mediacom \\
\hline & IDT & Leap Wireless & Mediaone \\
\hline & iGo & Level 3 Comm & Motient \\
\hline & Inflow & Loral & Net Talk \\
\hline & InPhonic & MCI & Netro \\
\hline & Intellectual Discovery & Nippon Tel & Network Solutions \\
\hline & Interactive Data & Pittway & Nextel \\
\hline & $\mathrm{J} 2$ & Premier Tech & NTS \\
\hline & LodgeNet & Research in Motion & Omnipoint \\
\hline & Long Distance & Reynolds\&Reynolds & PC-Tel \\
\hline & Metrocall & RSL Electronics & Pokertek \\
\hline & NCR & Rural Technologies & Ptek Holdings \\
\hline
\end{tabular}


Measuring Innovation Quality: A Patent Analysis

\begin{tabular}{|c|c|c|}
\hline Neon & Simtek & Purple Comm \\
\hline Net2Phone & Sprint Comm & Stratos Global \\
\hline Novatel Wireless & Telenor & SunGard \\
\hline Optel & Transaction Network & TCI International \\
\hline Orbital Sciences & TSR & Teleport \\
\hline Orix & Tyco Submarine & TeliaSonera \\
\hline Panamsat & Tyco Telecom & Teligent \\
\hline Pegasus & Valor Communication & T-Netix \\
\hline Polycom & Vanguard Semiconductor & TV Guide \\
\hline Public Service Solutions & Verizon & Usinternetworking \\
\hline Q Comm & Virgin Mobile & UTStarcom \\
\hline Quebecor & Voice Signal & WorldQuest \\
\hline Qwest Comm & Western Digital & XO Comm \\
\hline Raindance Comm & WorldCom & \\
\hline Raytheon & & \\
\hline Ses Americom & & \\
\hline Spectrasite & & \\
\hline Sunrise Telecom & & \\
\hline Syniverse Tech & & \\
\hline Telkonet & & \\
\hline Time Warner & & \\
\hline TiVo & & \\
\hline United States Cell & & \\
\hline Unity Semiconductor & & \\
\hline Viacom & & \\
\hline Voom & & \\
\hline Williams Comm & & \\
\hline Winstar Comm & & \\
\hline Xpedite Systems & & \\
\hline
\end{tabular}

Table 1: Cluster analysis

\begin{tabular}{|lcccc|}
\hline Indicators & Low & Medium-Low & Medium-High & High \\
\hline Technological Impact & Cluster 4 & Cluster 2 & Cluster 3 & Cluster 1 \\
\hline Originality & Cluster 4 & Cluster 1 & Cluster 3 & Cluster 2 \\
\hline Generality & Cluster 4 & Cluster 3 & Cluster 1 & Cluster 2 \\
\hline Size of Patent Portfolio & Cluster 4 & Cluster 2 & Cluster 3 & Cluster 1 \\
\hline
\end{tabular}

Table 2: Innovation quality for each cluster

As expected, the most prominent firms, Sony Corp., General Electric, Lucent Tech., AT\&T, Ericsson, and Qualcomm are included in the same group (Cluster 1). The most impactful patents belong to Sony Corp., General Electric, and Ericsson, whereas Qualcomm has the lowest value of technological impact followed by Lucent Technologies, and AT\&T. The generality index captures the breadth of applicability of an invention across various technology domains and firms in Cluster 1 show a medium-low generality index and not the highest one. This result can be explained by the strategy adopted by these firms, they might have focused their inventive activity efforts on a few but well-developed technologies. The top generality index for this cluster is observed for General Electric, Sony Corp., and Lucent Technologies; in the lowest positions, there are Ericsson, AT\&T, and Qualcomm. Surprisingly, the results regarding the generality index of firms in Cluster 1 are similar to those of originality index. As explained in the previous paragraphs, originality represents the breadth of the technology streams synthesized in a patented invention. General Electric seems to have built its patent portfolio on broader technologies suggesting a high-quality patent portfolio, followed by Sony Corp. and Lucent Technologies.

Firms included in Cluster 2 show a medium-low technological impact with high values for both generality and originality indicators. Firms with patents characterized by the highest technological impact are Raytheon followed by Cypress Semiconductor, NCR, Unity Semiconductor, Qwest Communications, Time Warner, General Dynamics, Polycom, and Comcast. Generality index is high for firms with very small portfolios such as Pegasus followed by AAT. Focusing on firms with a portfolio with more than 100 patents the highest generality index is observed for Unity Semiconductor, Armstrong World, Cypress Semiconductor, Polycom, Time Warner, Raytheon, NCR, General Dynamics, Qwest Communications and Comcast. Similarly, the highest originality index is observed for firms having a few patents, Long Distance, Interactive Data, Optel, Public Service Solutions, and AAT. When selecting top-10 companies, the podium is composed of Armstrong World, Raytheon, and NCR. The subsequent firms in this ranking are Polycom, Time Warner, Comcast, Cypress Semiconductor, Unity Semiconductor, General Dynamics, and Qwest Communications. 
Cluster 3 consists of firms with medium-high technological impact and medium generality and originality indicators. The top-10 firms with the highest technological impact are Research in Motion, Verizon Communications, Bellsouth, Avaya, Sprint Communications, Hughes, MCI, Nippon Tel, Western Digital, and WorldCom. Research in Motion followed by ITCX, Arch Wireless, MCI, Inter Tel, Tyco Submarine, Bellsouth, Infowave Software, Avaya, and Reynolds \& Reynolds, have the highest generality index. Firms with the highest originality value have very small portfolios, less than 10 patents in 15 years; this is the case of Rural Technologies, Intek Global, Atlantic Signal, Blackbox, Transaction Network, Vanguard, Valor Semiconductor and Valor Communications. If we consider the most significant portfolios (companies with more than 500 patents), the highest values of originality index are recorded for DirecTV, Hughes, MCI, Research in Motion, Western Digital, Avaya, Verizon Communications, Nippon Tel, Bellsouth, and Sprint Communications.

Finally, Cluster 4 encloses the companies with the lowest indexes. The worst position is for Teligent, Purple Communications, Usinternetworking, Crown Castle, Corridor Systems, SunGard, and Ptek Holdings. All these companies, have a low technological impact, low generality, and originality indexes and also a small number of patents. If we focus on the lowest performing firms regarding originality and generality of patent portfolios with more than 50 patents, there are Clearwire, TeliaSonera, Advanced Telecom, Alere, NTS, EMS Technologies, Nextel Communications, Globalstar, Omnipoint, Mediaone, Network Solutions, UTStarcom, and Ameritech.

\section{Discussion And Conclusion}

The present study investigated the innovation quality of firms operating in the U.S. communications industry. We grouped firms according to four patent indicators, the size of the patent portfolio, technological impact, originality, and generality. We further analyzed the industry patent trends. Results showed that large patent portfolios were spanned on a relatively small number of technology fields, suggesting a strategy focused on a better development of firm "core" technologies. The generality index confirmed this strategy because medium-low values signify a relatively narrow breadth of applicability of the patented inventions. However, these firms possessed impactful patents, their influence was higher than the industry average, denoting the presence of breakthrough innovations. These inventions had significant influence but they were not applied in a broad range of technology domains.

Moreover, the indicator of originality had a similar pattern like the generality index highlighting how big firms might have chosen search strategies on narrow technology fields. In contrast, firms with the highest originality and generality indicators had a medium-sized portfolio, showing how firms were trying to gain a competitive advantage and to establish their position in the market. Often, a high generality index is associated with high originality index denoting how the considerable inventive breadth embodied in the patent is reflected on subsequent inventions granted. Firms with a minimal number of patents behaved unpredictably, especially concerning generality and originality indicators. Some of them recorded the highest generality and originality indexes of the whole sample; others had the worst performance. The high variability points out how small firms were still exploring to survive in a market occupied by established firms.

Furthermore, firms that fell in the same cluster were likely to cooperate through alliances or to engage in M\&A. The most important transactions were the joint venture of Sony-Ericsson and the acquisition of MCI by Verizon Communication. The actors seemed to follow a similar strategy and to be complementary. In the case of Sony-Ericsson, they possessed different but brilliantly-developed "core" technologies, so both of them gained an advantage from competitive cooperation and increased their market share.

This work contributes to the innovation literature by highlighting the innovation quality dynamics and search strategies at an industry level, specifically by grouping firms according to their size of patent portfolio and quality of innovation. It also contributes to the identification of industry innovation trends. Future studies might focus on the phenomenon of M\&A and strategic alliances investigating how these events shape the acquirers' inventive activities. Finally, among the limitations worthy to note, is the fact that not all the inventions are patented because they do not fulfill the patentability conditions or because firms may rely on secrecy.

\section{References}

[1]. Ahuja, G., \& Lampert, C. M. (2001). Enterpreneurship in the large corporation: A longitudinal study of how established firms create breakthrough inventions. Strategic Management Journal, 521-543.

[2]. Kaplan, S., \& Vakili, K. (2015). The double- edged sword of recombination in breakthrough innovation. Strategic Management Journal, 36(10), 1435-1457.

[3]. Harrigan, K. R., Di Guardo, M. C., \& Marku, E. (2018). Patent value and the Tobin's q ratio in media services. The Journal of Technology Transfer, 43(1), 1-19.

[4]. Harrigan, K. R., \& Di Guardo, M. C. (2017). Sustainability of patent-based competitive advantage in the US communications services industry. The Journal of Technology Transfer, 42(6), 1334-1361.

[5]. Harrigan, K. R., Di Guardo, M. C., Marku, E., \& Velez, B. N. (2017). Using a distance measure to operationalise patent originality. Technology Analysis \& Strategic Management, 29(9), 988-1001. 
[6]. Harrigan, K. R., Di Guardo, M. C., \& Cowgill, B. (2017). Multiplicative-innovation synergies: tests in technological acquisitions. The Journal of Technology Transfer, 42(5), 1212-1233.

[7]. Di Guardo, M. C., \& Harrigan, K. R. (2016). Shaping the path to inventive activity: the role of past experience in R\&D alliances. The Journal of Technology Transfer, 41(2), 250-269.

[8]. Valentini, G., \& Di Guardo, M. C. (2012). M\&A and the profile of inventive activity. Strategic Organization, 10(4), 384-405.

[9]. Di Guardo, M. C., \& Valentini, G. (2007). Explaining the effect of M\&A on technological performance. In Advances in Mergers and Acquisitions (pp. 107-125). Emerald Group Publishing Limited.

[10]. Ernst, H. (2001). Patent applications and subsequent changes of performance: evidence from time-series cross-section analyses on the firm level. Research Policy, 143-157.

[11]. Belenzon, S., \& Patacconi, A. (2013). Innovation and firm value: An investigation of the changing role of patents, $1985-2007$. Research Policy, 1496-1510.

[12]. Archibugi, D., \& Pianta, M. (1996). Measuring technological change through patents and innovation surveys. Technovation, 451 468.

[13]. Schmookler, J. (1966). Invention and Economic Growth. Cambridge: Harvard University Press.

[14]. Scherer, F. (1982). Inter-Industry Technology Flows and Productivity Growth. Review of Economics and Statistics.

[15]. Scherer, F. M. (1965). Corporate inventive output, profits, and growth. Journal of Political Economy, 190-197.

[16]. Griliches, Z. (1984). R\&D, Patents and Productivity. NBER Conference Proceedings. University of Chicago Press.

[17]. Griliches, Z. (1990). Patent statistics as economic indicator: A survey. Journal of Economic literature, 1661-1707.

[18]. Trajtenberg, M. (1990). A penny for your quotes: Patent citations and the value of information. Rand Journal of Economics, 325342 .

[19]. Albert, M. B., Avery, D., Narin, F., \& McAllister, P. (1991). Direct validation of citation counts as indicators of industrially important patents. Research Policy, 20(3), 251-259.

[20]. Chen, Y.-S. (2011). Using patent analysis to explore corporate growth. Scientometrics, 433-448.

[21]. Danguy, J., De Rassenfosse, G., \& van Pottelsberghe de la Potterie, B. (2013). On the origins of the worldwide surge in patenting: an industry perspective on the R\&D-patent relationship. Industrial and Corporate Change, 23(2), 535-572.

[22]. Hall, B. H., \& Ziedonis, R. (2001). The patent paradox revisited: an empirical study on patenting in the U.S. semiconductor industry. Rand Jurnal of Economics, 101-128.

[23]. Ziedonis, R. H. (2004). Don't fence me in: Fragmented markets for technology and the patent acquisition strategies of firms. Management Science, 804-820.

[24]. Breitzman, A., \& Thomas, P. (2002). Using patent citation analysis to target/value M\&A candidates. Research Technology Management, 28-36.

[25]. Tseng, F.-M., Hsieh, C.-H., Peng, Y.-N., \& Chu, Y.-W. (2011). Using patent data to analyze trends and the technological strategies of the amorphous silicon thin-film solar cell industry. Technological Forecasting \& Social Change, 332-345.

[26]. Pakes, A., \& Griliches, Z. (1980). Patents and R\&D at the firm level: a first report. Economic Letters, 377-381.

[27]. Ernst, H. (1995). Patenting strategies in the German mechanical engineering industry and their relationship to company performance. Technovation, 225-240.

[28]. Blind, K., Edler, J., Frietsch, R., \& Schmoch, U. (2006). Motives to patent: empirical evidence from Germany. Research Policy, 655-672.

[29]. Curran, C.-S., Bröring, S., \& Leker, J. (2006). The front end of innovation process in an era of industry convergence: evidence from nutraceuticals and functional foods. R\&D Management, 487-498.

[30]. Karvonen, M., \& Kässi, T. (2013). Patent citations as a tool for analysing the early stages of convergence. Technological Forecasting \& Social Change, 1094-1107.

[31]. Kortum, S., \& Lerner, J. (1999). What is behind the recent surge in patenting. Research Policy, 1-22.

[32]. Benner, M., \& Waldfogel, J. (2008). Close to you? Bias and precision in patent-based measures of technological proximity. Research Policy, 1556-1567.

[33]. Castriotta, M., \& Di Guardo, M. C. (2016). Disentangling the automotive technology structure: a patent co-citation analysis. Scientometrics, 107(2), 819-837.

[34]. Narin, F. (1994). Patent Bibliometrics. Scientometrics, 147-155.

[35]. Karki, M. M. (1997). Patent Citation Analysis: A Policy Analysis Tool. World Patent Information, $269-272$.

[36]. Di Guardo, M. C., \& Harrigan, K. R. (2011). Mapping research on strategic alliances and innovation: a co-citation analysis. The Journal of Technological Transfer, 789-811.

[37]. Marku, E., Castriotta, E., \& Di Guardo, M. C. (2017). Disentangling the intellectual structure of innovation and M\&A literature. Technological Innovation Networks: Collaboration and Partnership, 47.

[38]. Hall, B. H., Jaffe, A. B., \& Trajtenberg, M. (2001). The NBER patent citation data file: Lessons, insights and methodological tools. NBER Working Paper No. 8498.

[39]. Jaffe, A. (1986). Technological opportunity and spillovers of R\&D: Evidence from firms' patents, profits, and market values. American Economic Review, 984-1001.

[40]. Jaffe, A. B., Fogarty, M. S., \& Banks, B. A. (1998). Evidence from patents and patent citations on the impact of NASA and other federal labs on commercial innovation. Journal of Industrial Economics, 183-205.

[41]. Mowery, D. C., Oxley, J. E., \& Silverman, B. S. (1996). Strategic Alliances and interfirm knowledge transfer. Strategic Management Journal, 77-91.

[42]. Marku, E. \& Zaitsava, M. (2018). Smart Grid Domain: Technology structure and innovation trends. International Journal of Economics, Business and Management Research, 2(4), 390-403.

[43]. Lanjouw, J. O., \& Schankerman, M. (2004). Patent Quality and Research Productivity: Measuring Innovation with Multiple Indicators. The Economic Journal, 441-465.

[44]. Argyres, N. S., \& Silverman, B. S. (2004). R\&D, organization structure, and the development of corporate technological knowledge. Strategic Management Journal, 929-958.

[45]. Lee, Y. G., Lee, J. D., Song, Y., \& Lee, S. J. (2007). An in-depth empirical analysis of patent citation counts using zero-inflated count data model: The case of KIST. Scientometrics, 27-39.

[46]. Fischer, T., \& Leidinger, J. (2014). Testing patent value indicators on directly observed patent alue- An empirical analysis of Ocean Tomo patent auctions. Research Policy, 519-529.

[47]. Park, G., \& Park, Y. (2006). On the measurement of patent stock as knowledge indicators. Technological Forecasting and Social Change, 793-812.

[48]. Hall, B. H., Jaffe, A. B., \& Trajtenberg, M. (2005). Market value and patent citations. The Rand Journal of Economics, 16-38. 
[49]. Hirschey, R., \& Richardson, V. (2003). Are scientific indicators of patent quality useful to investors? Journal of Empirical Finance, 91-107.

[50]. Patel, D., \& Ward, M. R. (2011). Using patent citation patterns to infer innovation market competition. Research Policy, 886-894.

[51]. Trajtenberg, M., Henderson, R., \& Jaffe, A. (1997). University versus corporate patents: A window on the basicness of invention". Economics of Innovation and New Technology, 19-50.

Elona Marku. " Measuring Innovation Quality: A Patent Analysis." IOSR Journal of Business and Management (IOSR-JBM) 20.8 (2018): 51-58. 